\title{
Impact of Canopy and Seasonal Dynamics on Different Forest Soil Microbial Community Composition in Mid Hills of Himachal Pradesh
}

\author{
Purnima Mehta*, P.K. Baweja, S.K. Bhardwaj and R.K. Aggarwal \\ Department of Environmental Science, Dr. Y.S. Parmar university of Horticulture and \\ Forestry Nauni, Solan, 173230 (Himachal Pradesh), India \\ *Corresponding author
}

\begin{tabular}{|c|}
\hline Keywords \\
\hline $\begin{array}{l}\text { Forest ecosystem, } \\
\text { Meteorological factors, } \\
\text { Microbial count, Soil } \\
\text { microbial biomass and } \\
\text { Soil nutrient pool }\end{array}$ \\
\hline Article Info \\
\hline $\begin{array}{l}\text { Accepted: } \\
\text { 06 August } 2018 \\
\text { Available Online: } \\
\text { 10 September } 2018\end{array}$ \\
\hline
\end{tabular}

\section{Introduction}

Quality and quantity of litter and various environmental factors in forest soils determine the microbial community composition. Litter decomposition rates depend on microbial community structure and activity (Esperschutz et al., 2013). Many studies has been reported for the impact of plant species and vegetation type (Meng et al., 2012; Banning et al., 2011) on soil microbial composition. Microbial
A substantial parameter that links plants to the soil is microbial biomass. Measurement of the biologically-active fractions of the soil organic matter, is a good way to quantify the quality of the soil. In the study, the impact of canopy and seasonal dynamics on different forest soil microbial community composition in Mid Hills of Himachal Pradesh were investigated in the forest floor under a stand of five forest ecosystems. Soil samples were collected from the organic layer and topsoil. Microbial biomass was determined by using soil fumigation extraction method and enumeration of microbial population was done by plate count technique through serial dilution using a variety of media. The study revealed that seasonal changes have a significant effect on the quantities of microbial biomass and count found in the forest floor. According to our study, the greatest amount of microbial biomass and count in the forest floor occurred during summer season. The total microbial count (Bacteria 206.97 $\mathrm{cfu} \mathrm{g}^{-1}$, Fungi 2.22 $\mathrm{cfu} \mathrm{g}^{-1}$ and Actinomycetes $8.78 \mathrm{cfu} \mathrm{g}^{-1}$ ) was found highest in Ban Oak Forest and about $1521.37 \mu \mathrm{g} \mathrm{C} \mathrm{g}^{-1}$ registered highest soil microbial biomass under Ban Oak Forest. The microbial properties followed the trend of Ban Oak Forest > Mixed Forest > Chir Pine Forest > Agriculture Field > Bare Area. The results indicates that litter quality and seasonal dynamics associated with different environmental factors like $\mathrm{pH}$, moisture and temperature are crucial in determining the relative abundance of soil microbial community found in different forest ecosystem. 
compared to changes in soil organic matter content or other soil physical and chemical properties (Pankhurst et al., 1997). Soil metabolic activities depend on microbial species composition, which in turn influenced by litter availability, soil type and other environmental factors (Samuel, 2010). The environmental factors that regulate microbial community composition may assist to understand soil biogeochemical processes (Keith- Roach et al., 2002). The seasonal changes affect the soil moisture, soil temperature, root activity and amount of organic matter give rise to fluctuations in the soil. Also, these fluctuations vary according to factors such as soil type, amount and type of vegetation, land use and management (Kramer and Green 2000; Chen et al., 2003).

Soil microorganisms are potentially useful indicators of soil health and quality. Soil microorganisms contribute to the maintenance of soil health and quality by controlling processes, such as decomposition of animalplant residues, biogeochemical cycles, formation of soil structure and its maintenance, and the fate of agrochemicals and pollutants applied to soil. Today, international programs for monitoring soil health and quality involve the measurement of several biochemical properties such as microbial biomass and microbial diversity (Nielsen and Winding, 2002; Alvarez et al., 2009).

In this study, we aim to evaluate the impact of canopy cover (oak and pine litter) and season dynamics on relative abundance of soil microbial community, soil organic and microbial biomass carbon in different forest ecosystem.

\section{Materials and Methods}

The study was conducted in different forest ecosystems at University campus of Nauni,
Solan, Himachal Pradesh. The investigation was carried out in Dr. Yashwant Singh Parmar University of Horticulture and Forestry Nauni, Solan (HP) during winter and summer season of 2015-16. The area is situated between $30.52^{\circ} \mathrm{N}$ and $77.10^{\circ} \mathrm{E}$ with elevation ranges from 1232 to $1264 \mathrm{~m}$. The research area was divided into five different sites as Chir Pine forest (F1), Mixed forest (F2), Ban Oak forest (F3), Agricultural field (F4) and Bare area (F5) as shown in Figure 1.

Ecology and biological properties were determined in the laboratory by using following methods:

\section{Litter layer characteristics}

A general forest floor survey was conducted at each forest using destructive sampling and percent coverage of litter, moss and plant species were recorded as shown in Table 1. A destructive sampling method was used over the two seasons (winter and summer) to collect seasonal data at 1400-1600 hrs on litter and moss moisture content through various drying and wetting periods along altitudinal variations as described by Wotton et al., (2005).

\section{Destructive sampling technique}

Destructive sampling method was used to measure mean surface loading by collecting the samples at each sampling location using a $900 \mathrm{~cm}^{2}$ grid. Averages amongst the four replicates in different forests viz., Chir pine forest $\left(F_{1}\right)$, Mixed forest $\left(F_{2}\right)$ and Ban oak forest $\left(\mathrm{F}_{3}\right)$ for each substrate layer were used to determine a value for total surface loading at each site. Surface thickness of litter layer was measured with the help of meter rod. However, the forest ecosystem having different forest vegetation have dead and decaying material lying on the ground as per the forest area and no such material was found 
in agriculture field and bare area (control conditions). Therefore, for completion of minimum requirement of design (RBD factorial) and for statistical analysis of litter layer characteristics, the number of replications have been increased to four by considering different forest types viz., chir pine forest $\left(\mathrm{F}_{1}\right)$, mixed forest $\left(\mathrm{F}_{2}\right)$ and ban oak forest $\left(\mathrm{F}_{3}\right)$, during winter and summer seasons of 2015-2016.

\section{Total microbial count}

The enumeration of microbial population was done by plate count technique through serial dilution using a variety of media (Wollum, 1982).

\section{Microbial biomass}

The biomass was obtained by using soil fumigation- extraction method given by Vance et al., (1987).

\section{Results and Discussion}

The important litter layer characteristics Viz. surface loading and surface thickness were taken into account to exhibit significant microclimatic variation under selected forest ecosystem results obtained are presented as under:

\section{Surface loading}

The data represents the interaction of mean surface loading in three different forest types during winter and summer season 2015-2016 as shown in Table 2. Significant difference was found between three forests in mean surface loading during winter and summer seasons. The maximum surface loading of $\left(1.75 \mathrm{~kg} \mathrm{~m}^{-2}\right)$ was observed in Chir pine forest $\left(\mathrm{F}_{1}\right)$ and minimum of $\left(0.24 \mathrm{~kg} \mathrm{~m}^{-2}\right)$ in mixed forest $\left(\mathrm{F}_{2}\right)$. The maximum surface loading was found in summer season $\left(0.93 \mathrm{~kg} \mathrm{~m}^{-2}\right)$ than winter season $\left(0.61 \mathrm{~kg} \mathrm{~m}^{-2}\right)$. The interaction of forest type $\mathrm{X}$ season on surface loading of mid hills of HP was found to be significant. The maximum surface loading was found in chir pine forest $\left(\mathrm{F}_{1}\right)$ during summer season $(2.16$ $\left.\mathrm{kg} \mathrm{m}^{-2}\right)$ and minimum in mixed forest $\left(\mathrm{F}_{2}\right)$ during summer season $\left(0.16 \mathrm{~kg} \mathrm{~m}^{-2}\right)$. The results were probably due to woody material was found on the surface of forest floor of chir pine forest consisted of volatile material with minimum decomposition rate, year to year build up as compared to ban oak and mixed forest.

\section{Surface thickness}

Table 2 depicts the microclimatic seasonal variations and interactions of surface thickness in all forest types during winter and summer season in 2015-2016. Significant differences were obtained in all three forests during winter and summer seasons. The maximum surface thickness of $(2.91 \mathrm{~cm})$ was found in chir pine forest $\left(\mathrm{F}_{1}\right)$ and minimum in ban oak forest $\left(\mathrm{F}_{3}\right)$ $(1.28 \mathrm{~cm})$. Surface thickness of summer season $(2.02 \mathrm{~cm})$ was significantly higher than winter season $(1.58 \mathrm{~cm})$. The interaction of forest type $\mathrm{X}$ season on surface thickness of mid hills of HP was found to be significant. The maximum surface thickness $(3.52 \mathrm{~cm})$ was found in chir pine forest $\left(\mathrm{F}_{1}\right)$ during summer season and minimum $(0.82 \mathrm{~cm})$ in mixed forest $\left(\mathrm{F}_{2}\right)$ during summer season which was statistically at par with ban oak forest $\left(\mathrm{F}_{3}\right)$ $(0.83 \mathrm{~cm})$ during winter season. The results were probably due to structure and composition of the decomposed material, the underlying organic layer and soil. The results are in consonance with Sohng et al., (2014) and Nelson (2001).

The important biological properties Viz. microbial count and microbial biomass were analysed for studying the microclimatic variations among different forest ecosystem. The results obtained are presented as under: 


\section{Microbial count}

The perusal of the data revealed in Table 3 a significant difference in the microbial count among different forest ecosystem and seasons. The highest bacterial count was observed in ban oak forest $\left(\mathrm{F}_{3}\right)\left(206.97 \mathrm{cfu} \mathrm{g}^{-1}\right)$ followed by mixed forest $\left(\mathrm{F}_{2}\right)\left(203.68 \mathrm{cfu} \mathrm{g}^{-1}\right)$ and chir pine forest $\left(\mathrm{F}_{1}\right)\left(161.77 \mathrm{cfu} \mathrm{g}^{-1}\right)$. The lowest bacterial count was observed under bare area $\left(\mathrm{F}_{5}\right)$ of $40.50 \mathrm{cfu} \mathrm{\textrm {g } ^ { - 1 }}$. The maximum bacterial count of $182.93 \mathrm{cfu} \mathrm{g}^{-1}$ was observed in summer season and minimum (118.65 $\left.\mathrm{cfu} \mathrm{g}^{-1}\right)$ in winter season. In microclimatic interaction effect, the bacterial count of soils of different forest ecosystem was ranged between (254.67$33.67 \mathrm{cfu} \mathrm{g}^{-1}$ ). The highest bacterial count was recorded Inban oak forest $\left(\mathrm{F}_{3}\right)\left(254.67 \mathrm{cfu} \mathrm{g}^{-1}\right)$ in summer season which was statistically at par with mixed forest $\left(\mathrm{F}_{2}\right)\left(253.00 \mathrm{cfu} \mathrm{g}^{-1}\right)$ in summer season and lowest in bare area $\left(\mathrm{F}_{5}\right)$ $\left(33.67 \mathrm{cfu} \mathrm{g}^{-1}\right)$ in winter season.

Fig.1 Location map of different Ecosystems

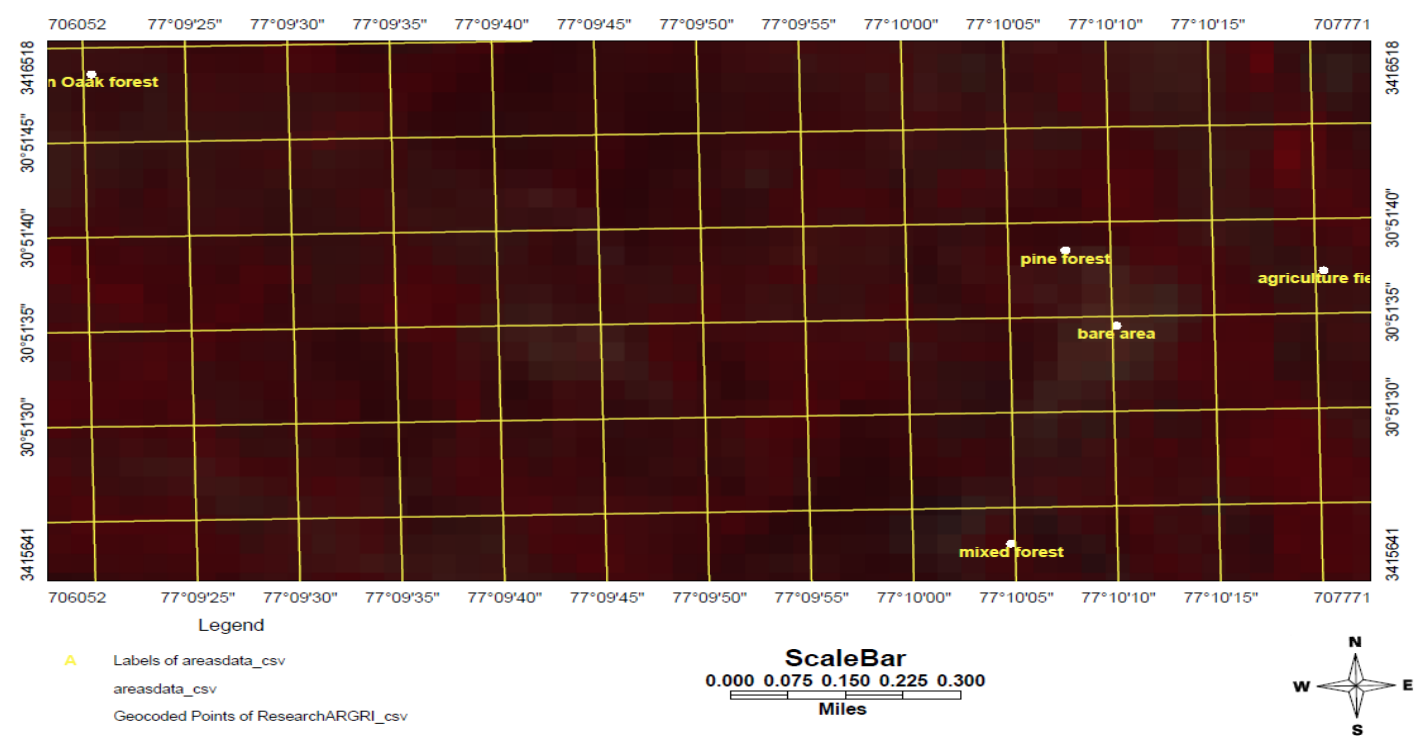

Fig.2 Climatograph of the year (Nov-May) 2015 - 2016

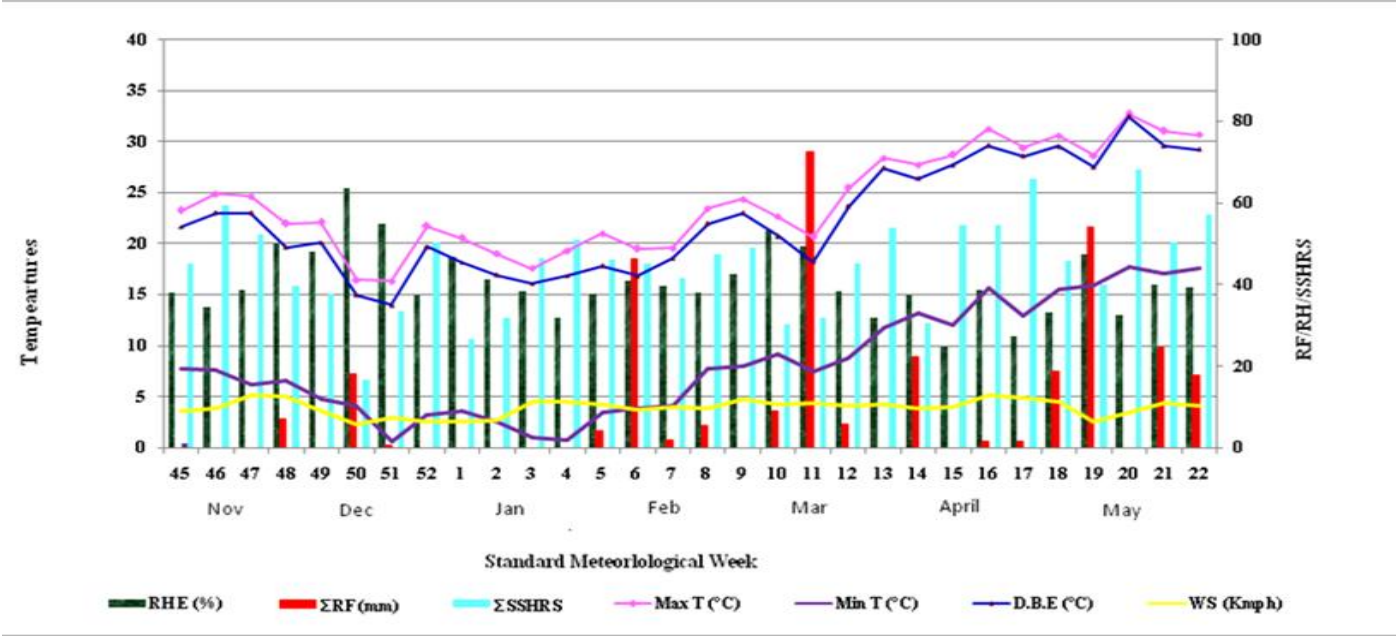


Table.1 Ecology of selected sites studied in different ecosystem

\begin{tabular}{|c|c|c|c|c|c|c|c|}
\hline \multirow[t]{2}{*}{ Sr. No. } & Botanical Name & Local Name & $\mathbf{F}_{1}$ & $\mathbf{F}_{2}$ & $\mathbf{F}_{3}$ & $\mathbf{F}_{4}$ & $\mathbf{F}_{5}$ \\
\hline & \multicolumn{2}{|c|}{ Trees } & & & & & \\
\hline 1 & Pinus roxburghii & Chir & + & & & & \\
\hline 2 & Quercu sleucotrichophora & Oak & & + & + & & \\
\hline 3 & Jacaranda mimosifolia & Gulmohar & & + & & & \\
\hline 4 & Toona ciliata & Tooni & & + & & & \\
\hline 5 & Dalbergia sissoo & Shisham & & + & & & \\
\hline 6 & Pyrus pashia & Kainth & & + & & & \\
\hline 7 & Albizia chinensis & Siris & & + & & & \\
\hline 8 & Grewia optiva & Bhuel & & + & & & \\
\hline 9 & Celtis australis & Khirik & & + & & & \\
\hline 10 & Salix alba & White willow & & + & & & \\
\hline \multirow{2}{*}{11} & Syzygium cumini & Jamun & & + & & & \\
\hline & \multicolumn{2}{|c|}{ Shrubs } & $\mathbf{F}_{1}$ & $\mathbf{F}_{2}$ & $\mathbf{F}_{3}$ & $\mathbf{F}_{4}$ & $\mathbf{F}_{5}$ \\
\hline 12 & Berberis lyceum & Kashmal & & + & & & \\
\hline 13 & Woodfordia floribunda & Dhai & + & + & + & & \\
\hline 14 & Bidens pilosa & Kumber & + & + & + & & \\
\hline 15 & Rosa species & Kuja & + & + & & & \\
\hline 16 & Rubus ellipticus & Akha & + & + & & & \\
\hline 17 & Cestrum noctrnum & Rat ki rani & & + & & & \\
\hline 18 & Sarcococcasaligna & Diun & + & & & & \\
\hline 19 & Carissa carandas & Karaunda & + & + & & & \\
\hline \multirow[t]{2}{*}{20} & Myrsine africana & Jhunjhara & + & & + & & \\
\hline & \multicolumn{2}{|l|}{ Herbs } & $\mathbf{F}_{1}$ & $\mathbf{F}_{2}$ & $\mathbf{F}_{3}$ & $\mathbf{F}_{4}$ & $\mathbf{F}_{5}$ \\
\hline 21 & Artemesia vulgaris & Khardar & + & & & & \\
\hline 22 & Calotropis procera & Aak & + & + & & & \\
\hline 23 & Datura stramonium & Dhatura & + & & & & \\
\hline 24 & Fragaria vesca & Wild strawberry & + & + & + & & \\
\hline 25 & Thalictrum fendleri & Meadow rue & + & + & + & & \\
\hline 26 & Rumex nepalensis & JungliPalak & + & + & + & & \\
\hline 27 & Urticadioica & Bichhubutti & + & + & + & & \\
\hline \multirow[t]{2}{*}{28} & Viola canescens & Banafsa & + & + & + & & \\
\hline & \multicolumn{2}{|c|}{ Grasses } & & & & & \\
\hline 29 & Chrysopogon species & Dholu & + & + & + & & + \\
\hline 30 & Cynodondactylon & Makora & + & + & + & + & + \\
\hline 31 & Eulaliopsis binata & Bhabbar & & + & & & \\
\hline 32 & Hetropogoncontortus & Lamb Sariala & + & + & + & & \\
\hline 33 & Dicanthium spp & Marvel grass & & + & + & & \\
\hline \multirow[t]{2}{*}{34} & Themeda anathera & - & + & + & & & \\
\hline & \multicolumn{2}{|l|}{ Ferns } & & & & & \\
\hline 35 & Nephrolepis spp & Boston fern & & & & & \\
\hline \multirow[t]{2}{*}{36} & Cheilanthes argentea & Silver fern & & & & & \\
\hline & \multicolumn{2}{|c|}{ Agriculture crop } & & & & & \\
\hline 37 & Lens culinaris & Masoor dal & & & & + & \\
\hline
\end{tabular}


Int.J.Curr.Microbiol.App.Sci (2018) 7(9): 494-502

Table.2 Seasonal variation in surface loading and surface thickness under different forest ecosystem in mid hills of Himachal Pradesh

\begin{tabular}{|c|c|c|c|c|c|c|}
\hline \multirow[t]{2}{*}{ Forest ecosystem } & \multicolumn{3}{|c|}{ Surface loading $\left(\mathrm{kg} \mathrm{m}^{-2}\right)$} & \multicolumn{3}{|c|}{ Surface Thickness (cm) } \\
\hline & Winter & Summer & Mean & Winter & Summer & Mean \\
\hline Chir Pine forest $\left(\mathrm{F}_{1}\right)$ & 1.33 & 2.16 & 1.75 & 2.31 & 3.52 & 2.91 \\
\hline Mixed forest $\left(\mathrm{F}_{2}\right)$ & 0.31 & 0.16 & 0.24 & 1.14 & 0.82 & 0.98 \\
\hline Ban oak forest $\left(\mathrm{F}_{3}\right)$ & 0.20 & 0.49 & 0.34 & 0.83 & 1.73 & 1.28 \\
\hline Mean & 0.61 & 0.93 & & 1.42 & 2.02 & \\
\hline $\mathrm{CD}_{0.05}$ & \multicolumn{3}{|c|}{$\begin{array}{l}\text { Forest }(\mathrm{F}): 0.04 \\
\text { Season }(\mathrm{S}): 0.03 \\
\text { Forest X Season }(\mathrm{FxS}): 0.06\end{array}$} & \multicolumn{3}{|c|}{$\begin{array}{l}\text { Forest }(\mathrm{F}): 0.33 \\
\text { Season }(\mathrm{S}): 0.27 \\
\text { Forest X Season }(\mathrm{FxS}): 0.47\end{array}$} \\
\hline
\end{tabular}

Table.3 Seasonal variation in soil microbial count under different forest ecosystem in mid hills of Himachal Pradesh

\section{Microbial count (cfu g $\mathrm{g}^{-1}$ )}

\begin{tabular}{|c|c|c|c|c|c|c|c|c|c|}
\hline \multirow[t]{2}{*}{ Forest ecosystem } & \multicolumn{3}{|c|}{ Bacteria $\left(10^{5}\right)$} & \multicolumn{3}{|c|}{ Fungi $\left(10^{3}\right)$} & \multicolumn{3}{|c|}{ Actinomycetes $\left(10^{5}\right)$} \\
\hline & Winter & Summer & Mean & Winter & Summer & Mean & Winter & Summer & Mean \\
\hline $\begin{array}{l}\text { Chir Pine forest } \\
\left(F_{1}\right)\end{array}$ & 128.21 & 195.33 & 161.77 & 2.10 & 2.92 & 2.51 & 6.68 & 8.47 & 7.57 \\
\hline Mixed forest $\left(\mathrm{F}_{2}\right)$ & 154.37 & 253.00 & 203.68 & 1.64 & 2.73 & 2.19 & 7.96 & 8.87 & 8.42 \\
\hline Ban oak forest $\left(F_{3}\right)$ & 159.27 & 254.67 & 206.97 & 1.54 & 2.90 & 2.22 & 8.40 & 9.15 & 8.78 \\
\hline $\begin{array}{l}\text { Agriculture field } \\
\left(\mathrm{F}_{4}\right)\end{array}$ & 117.75 & 164.33 & 141.04 & 1.46 & 2.42 & 1.94 & 5.11 & 6.10 & 5.61 \\
\hline $\operatorname{Bare} \operatorname{area}\left(\mathbf{F}_{5}\right)$ & 33.67 & 47.33 & 40.50 & 1.08 & 1.28 & 1.18 & 3.50 & 4.15 & 3.83 \\
\hline Mean & 118.65 & 182.93 & & 1.56 & 2.45 & & 6.33 & 7.35 & \\
\hline $\mathrm{CD}_{0.05}$ & \multicolumn{3}{|c|}{$\begin{array}{l}\text { Forest }(\mathrm{F}): 3.89 \\
\text { Season }(\mathrm{S}): 2.46 \\
\text { Forest x Season }(\mathrm{FxS}): 5.49\end{array}$} & \multicolumn{3}{|c|}{$\begin{array}{l}\text { Forest }(F): 0.07 \\
\text { Season }(S): 0.04 \\
\text { Forest x Season }(F x S): 0.10\end{array}$} & \multicolumn{3}{|c|}{$\begin{array}{l}\text { Forest }(F): 0.10 \\
\text { Season }(S): 0.07 \\
\text { Forest x Season }(F x S): 0.15\end{array}$} \\
\hline
\end{tabular}

Table.4 Seasonal variation in Soil Microbial Biomass under different forest ecosystem in mid hills of Himachal Pradesh

\begin{tabular}{|l|c|c|c|}
\hline Forest ecosystem & Winter Season & Summer Season & Mean \\
\hline Chir Pine forest $\left(\mathbf{F}_{\mathbf{1}}\right)$ & 764.88 & 1878.77 & 1321.83 \\
\hline Mixed forest $\left(\mathbf{F}_{\mathbf{2}}\right)$ & 817.83 & 2035.88 & 1426.86 \\
\hline Ban oak forest $\left(\mathbf{F}_{\mathbf{3}}\right)$ & 825.24 & 2217.50 & 1521.37 \\
\hline Agriculture field $\left(\mathbf{F}_{\mathbf{4}}\right)$ & 237.66 & 925.36 & 581.51 \\
\hline Bare area $\left(\mathbf{F}_{\mathbf{5}}\right)$ & 133.76 & 255.66 & 194.71 \\
\hline Mean & 555.87 & 1462.63 & \\
\hline $\mathbf{C D}_{\mathbf{0 . 0 5}}$ & Forest $(\mathrm{F}): 56.36$ & & \\
& Season $(\mathbf{S}): 35.65$ & & \\
& Forest x Season $(\mathrm{F} \mathrm{x} \mathrm{S):} 79.70$ &
\end{tabular}


The actinomycetes population was found to be highest in the ban oak forest $\left(\mathrm{F}_{3}\right)(8.78 \mathrm{cfu}$ $\left.\mathrm{g}^{-1}\right)$ followed by mixed forest $\left(\mathrm{F}_{2}\right)(8.42 \mathrm{cfu}$ $\left.\mathrm{g}^{-1}\right)$ and chir pine forest $\left(\mathrm{F}_{1}\right)\left(7.57 \mathrm{cfu} \mathrm{g}^{-1}\right)$. The lowest soil actinomycetes count of 3.83 $\mathrm{cfu} \mathrm{g}^{-1}$ was observed under bare area $\left(\mathrm{F}_{5}\right)$. The actinomycetes population in summer was found to be highest (7.35 $\mathrm{cfu} \mathrm{\textrm {g } ^ { - 1 }}$ ) and in winter to be lowest $\left(6.33 \mathrm{cfu} \mathrm{g}^{-1}\right)$. In microclimatic interaction effect, the highest population of actinomycetes was found in ban oak forest $\left(F_{3}\right)\left(9.15 \mathrm{cfu} \mathrm{g}^{-1}\right)$ in summer season and lowest was found in bare area $\left(\mathrm{F}_{5}\right)(3.50$ cfu $\mathrm{g}^{-1}$ ) in winter season.

The fungal population was observed to be the highest in chir pine forest $\left(\mathrm{F}_{1}\right)\left(2.51\right.$ cells $\left.^{-1}\right)$ and lowest soil fungal population was observed under bare area $\left(\mathrm{F}_{5}\right)\left(1.18\right.$ cells $\left.\mathrm{g}^{-1}\right)$. The summer season showed the highest soil fungal population of 2.45 cells $\mathrm{g}^{-1}$ and winter season showed the lowest of 1.56 cells $\mathrm{g}^{-1}$.

The interaction of forest ecosystem $\mathrm{X}$ season on soil fungal count of mid hills of HP was found to be significant. The highest was found in chir pine forest $\left(F_{1}\right) 2.92$ cells $g^{-1}$ in summer season which was statistically at par with ban oak forest $\left(\mathrm{F}_{3}\right) 2.90$ cells $\mathrm{g}^{-1}$ in summer season, and found lowest in bare area $\left(\mathrm{F}_{5}\right) 1.08$ cells $\mathrm{g}^{-1}$ in winter season.

Significantly higher bacterial and actinomycetes count was found in ban oak and mixed forest as compared to bare area were probably due to presence of higher organic carbon in the soils whereas fungal count was found to be higher in chir pine forest due to high acidic nature of soil $(\mathrm{pH}=5.36)$.

The microbial count was higher in summer season than winter season due maximum air temperature in summer because microbial activities increase with increase in temperature as shown in Figure 2.

\section{Microbial biomass}

Soil biomass significantly varied within the areas at different selected forest ecosystem in all the locations during winter and summer season 2015-2016 as shown in Table 4. Significantly maximum soil microbial

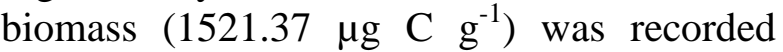
under ban oak forest $\left(\mathrm{F}_{3}\right)$. Whereas, minimum soil microbial biomass was recorded under bare area $\left(\mathrm{F}_{5}\right)\left(194.71 \mu \mathrm{g} \mathrm{C} \mathrm{g}^{-1}\right)$. Significantly highest soil microbial biomass of $1462.63 \mu \mathrm{g}$ $\mathrm{C} \mathrm{g}^{-1}$ ) was recorded during summer season and lowest of $555.87 \mu \mathrm{g} \mathrm{C} \mathrm{g}{ }^{-1}$ during winter season.

The data presented in Table 4 further revealed that five different forest ecosystem (F) X seasons ( $\mathrm{S}$ ) interaction which also results a significant influence on soil microbial biomass distribution. Ban oak forest $\left(\mathrm{F}_{3}\right)$ registered highest soil microbial biomass of (2217.50 $\mu \mathrm{g} \mathrm{C} \mathrm{g}^{-1}$ ) during summer season is in line with Vance et al., (1987) who had reported $61-2000 \mathrm{mg} \mathrm{kg}^{-1}$ of soil biomass carbon under temperate and tropical forests.

However, minimum soil microbial biomass of (133.76 $\mu \mathrm{g} \mathrm{C} \mathrm{g}^{-1}$ ) was observed in winter season in bare area $\left(\mathrm{F}_{5}\right)$ may be ascribed due to low return of organic material to such area. The low level of organic substrate for microbes and reduced mineralization rates due to unfavorable conditions like compaction, low soil moisture content and nutrient levels may be ascribed for reduced soil microbial biomass in bare area as compared to forest ecosystem.

Results obtained in this study clearly demonstrated that the amount of microbial biomass and count was observed in forest soil are different and generally higher in the forest floor. Our results also showed that in forest floor soil microbial biomass and count change in accordance with soil moisture, soil 
temperature, organic matter content and structure of microbial community.

Seasonal changes in environmental conditions such as temperature and moisture facilitate the turnover of microbial biomass and consequently can perform an important role in controlling nutrient availability. Higher microbial biomass and count have usually been observed in summer season while lower values in winter. Because microbial biomass is used as indicator of soil activity, our findings suggest that under the very humid region of forest ecosystem, soil may be more active in summer than in winter.

\section{Acknowledgement}

The assistance provided by Dr S K Bhardwaj Prof. \& Head, Department of Environmental Science, and Dr. R.K. Gupta, Professor (Statistics), Department of Basic Sciences, Dr Y S Parmar University of Horticulture and Forestry, Nauni, HP-India in the present study is highly acknowledged.

\section{References}

Alvarez, E., Torrado, V.M., Fernandez Marcos M.L. and Diaz-Ravia, M. 2009. Microbial biomass and activity in a forest soil under different tree species. Electronic Journal of Environmental, Agricultural and Food Chemistry. 8 (9): 878-887.

Banning, N.C., Gleeson, D.B., Grigg, A.H., Grant, C.D., Andersen, G.L., Brodie, E.L. and Murphy, D.V. 2011. Soil microbial community successional patterns during forest ecosystem restoration. Appl Environ Microbiol. 77: 6158-6164.

Chapman, S.K., Newman, G.S., Hart, S.C., Schweitzer, J.A., Koch and G.W. 2013. Leaf Litter Mixtures Alter Microbial Community Development: Mechanisms for Non- Additive Effects in Litter Decomposition. PLoS ONE. 8: e62671.

Chen, C. R., Condron, L. M., Davis, M. R. and Sherlock, R. R. 2003. Seasonal changes in soil phosphorus and associated microbial properties under adjacent grassland and forest in New Zealand. Forest Ecology and Management 177: 539-557.

Esperschutz, J., Zimmermann, C., Dumig, A., Welz, G., Buegger, F., Elmer, M., Munch, J.C. and Schloter, M. 2013. Dynamics of microbial communities during decomposition of litter from pioneering plants in initial soil ecosystems. Biogeosciences. 10: 51155124.

Keith-Roach, M.J., Bryan, N.D., Bardgett, R.D. and Livens, F.R. 2002. Seasonal changes in the microbial community of a salt marsh, measured by phospholipid fatty acid analysis. Biogeochemistry. 60: 77-96.

Kramer, S. and Green, D. M. 2000. Acid and alkaline phosphatase dynamics and their relationship to soil microclimate in a semiarid woodland. Soil Biology and Biochemistry. 32: 179-188.

Meng, F.J., Huang, F.L., Wang, Q. 2012. The effects of exotic and native poplars on rhizosphere soil microbe and enzyme activity. Afr J Biotechnol. 11: 14121418.

Nelson, R.M. 2001. Water relations of forest fuels. In: Forest fires: Behaviuor and ecological effects (A. Johnson and K. Miyanishi, eds.). Academic press. San Diego, California. 79-143

Nielsen, M. N. and Winding, A. 2002. Microorganisms as Indicators of Soil Health. National Environmental Research Institute, Technical Report No. 388, Denmark 1-84.

Pankhurst, C. E., Doube, B. M. and Gupta, V. V. S. R. 1997. Biological indicators of soil health: synthesis. In: C. E. 
Pankhurst, B. M. Doube, V. V. S. R Gupta (eds). Biological Indicators of Soil Health, Wallingford, UK: CAB International, pp: 419-435.

Samuel, A.D. 2010. Dehydrogenase: An indicator of biological activities in a preluvo soil. Res J Agr Sci. 42: 306-310.

Sohng, J., Reum, Han. A. H., Jeong, M. A., Park, Y., Park, B. B., and Park, P. S. 2014. Seasonal pattern of decomposition and $\mathrm{N}, \mathrm{P}$, and $\mathrm{C}$ dynamics in leaf litter in a Mongolian Oak Forest and a Korean Pine plantation. Forests. 5: 2561-2580
Vance, E.D., Brooks, P.C., and Jenkinson, D. S. 1987. An extraction method for measuring soil microbial biomass carbon. Soil Biology and Biochemistry. 19:703-707

Wollum, A.G. 1982. Cultural methods for Soil Microorganisms. In: Methods of soil analysis. American Society of Agronomy Madison. 781-813 p.

Wotton, B.M., Stocks, B.J., and Martell, D.L. 2005. An index for tracking sheltered forest floor moisture within the Canadian forest fire weather index system. International Journal of Wildland Fire. 14(2): 169-182

\section{How to cite this article:}

Purnima Mehta, P.K. Baweja, S.K. Bhardwaj and Aggarwal, R.K. 2018. Impact of Canopy and Seasonal Dynamics on Different Forest Soil Microbial Community Composition in Mid Hills of Himachal Pradesh. Int.J.Curr.Microbiol.App.Sci. 7(09): 494-502.

doi: https://doi.org/10.20546/ijcmas.2018.709.059 